\title{
NADZÓR NA PODSTAWIE RYZYKA JAKO METODA NADZORU ADMINISTRACYJNEGO
}

\section{NADZORCZA FUNKCJA ADMINISTRACJI}

Jedną z istotnych funkcji administracji publicznej jest nadzór nad określonym obszarem życia społecznego. Ustawodawca w wielu wypadkach, gdy reguluje określony obszar życia społecznego, ustanawia organ administracji, któremu przyznaje rolę nadzorcy nad tym obszarem, a ściślej: nad podmiotami w ramach tego obszaru. Organ, który ma tak określone zadanie, zostaje wyposażony w rozmaite kompetencje, mające służyć sprawowaniu tego nadzoru. Moga to być m.in. kompetencje do pozyskiwania informacji $\mathrm{w}$ trybie zapytania skierowanego od organu do podmiotu nadzorowanego, w trybie sprawozdawczości bez zapytania organu czy też w trybie kontroli (inspekcji), a także kompetencje do wyrażania zgody na określone zachowania podmiotów nadzorowanych, kompetencje do nakładania sankcji administracyjnych za naruszenia. Jednakże same kompetencje i ich legislacyjne ujęcie nie przesądzają o sposobie wykonywania tych kompetencji, zwłaszcza tych, których wykonywanie uwarunkowane jest kategoria uznania administracyjnego, a także takich, w których inicjatywa ich wykonywania zależy od organu administracji.

Organy nadzoru administracyjnego samodzielnie wypracowują metodologię wykonywania przyznanych im kompetencji dla optymalnej realizacji wyznaczonych celów. Często organy nadzoru staną wobec sytuacji, w której obszary podlegające ich nadzorowi będą bardzo rozległe w sensie merytorycznym lub podmiotowym, a zasoby, przede wszystkim ludzkie, przyznane do wykonywania nadzoru, będą niewystarczające dla całkowitego czy bardzo szerokiego pokrycia czynnościami nadzorczymi obszarów powierzonych pieczy organów. W takich sytuacjach organ może wykonywać swoje kompetencje wyłącznie selektywnie. Oczywiście chodzi tu o takie kompetencje, których wykonywanie zależy od woli organu nadzoru, np. przeprowadzenie kontroli. W praktyce nie jest możliwy holistyczny model nadzoru, a więc taki, w którym organ nadzoru nadzoruje każdy podmiot nadzorowany oraz w każdym obszarze stanu czy funkcjonowania tego podmiotu. W praktyce możliwy jest tylko selektywny nadzór. Dlatego też dla prawidłowej realizacji funkcji nadzorczych i celów nadzorczych bardzo ważne jest, aby w ramach modelu nadzoru selektywnego odnaleźć i zastosować optymalną metodę dopasowania realnych możliwości nadzorczych do zadań i celów nadzorczych. Zatem podstawowe pytanie dotyczy metody doboru środków nadzoru, podmiotu oraz obszaru wykonywania kompetencji nadzorczych. 


\section{NADZÓR NA PODSTAWIE RYZYKA (NPR)}

\section{NPR jako proces zarządzania ryzykiem (mikro- i makro-NPR)}

Jedna $\mathrm{z}$ takich metod wypracowanych $\mathrm{w}$ praktyce jest metoda nadzoru na podstawie ryzyka (risk based supervision - RBS). Metoda ta powstała i rozwinęła się $\mathrm{w}$ amerykańskim nadzorze bankowym ${ }^{1}$, skąd została przeniesiona do nadzoru bankowego $\mathrm{w}$ innych państwach, a następnie została przeniesiona do nadzoru innych sektorów rynku finansowego (ubezpieczeniowego, emerytalnego, kapitałowego) w wielu administracjach na całym świecie ${ }^{2}$. W latach 20010-2011 została także wdrożona przez polską Komisję Nadzoru Finansowego ${ }^{3}$.

Pojęcie $\mathrm{RBS}^{4}$ jest różnie ujmowane i definiowane, jednakże na gruncie niniejszego opracowania nadzór na podstawie ryzyka (dalej: NPR) będzie oznaczał metodę nadzoru administracyjnego polegająca na takich działaniach organu, które są dopasowane do ryzyka stwarzanego przez podmioty nadzorowane dla określonej wartości ${ }^{5} \mathrm{w}$ obszarze podlegającym nadzorowi danego organu. Przykładem ujęcia NPR w literaturze brytyjskiej jest ujęcie J. Black, która definiuje NPR jako systematyczne podejście nadzorcze skonstruowane $\mathrm{w}$ celu zarządzania ryzykiem organu nadzoru: ryzykiem nieosiągnięcia celów wyznaczonych temu organowi. W ujęciu tym NPR polega na ustanowieniu ram oraz procedur podejmowania decyzji w celu ustanowienia priorytetów działań nadzorczych i zaangażowania zasobów, przede wszystkim w odniesieniu do inspekcji i egzekucji (enforcement), odpowiednio do ryzyka, jakie nadzorowane podmioty stwarzają dla celów, które zostały wyznaczone do osiaggnięcia organowi nadzoru ${ }^{6}$. Zatem $w$ tym ujęciu NPR to metoda zarządzania ryzykiem organu nadzoru - ryzykiem, jakie zagraża celom tego organu ${ }^{7}$. Ponieważ cele organu nadzoru będą związane zazwyczaj z zapewnieniem określonych wartości czy też ,jakości” w danym obszarze życia społecznego, można to nazwać ujęciem makro-NPR.

Metodę makro-NPR stosuje się na poziomie całości lub wyodrębnionej części obszaru nadzorowanego przez organ - w wymiarze podmiotowym lub przedmiotowym. W tym wypadku organ administracji przede wszystkim analizuje całość lub część obszaru powierzonego jego nadzorowi, definiuje, które podmioty lub negatywne zjawiska mogą zagrażać jego celom, wartości czy też ,jakości”

${ }^{1}$ G. Brunner, R. Hinz, R. Rocha, Risk-Based Supervision of Pension Funds: A Review of International Experience and Preliminary Assessment of the First Outcomes, The World Bank Policy Research Working Paper, nr 4491, s. 6 i n.

${ }^{2}$ Zob. np. A. Nadolska, Model nadzoru opartego na ocenie ryzyka na przyktadzie doświadczeń Financial Services Authority w ramach struktury ARROW, „Monitor Prawa Bankowego” 2011, nr 6.

${ }^{3}$ Zob. komunikat na: http://www.knf.gov.pl/o_nas/urzad_komisji/bion/index.html (dostęp: 2.03.2012).

${ }^{4}$ Zob. omówienie w opracowaniu J. Black, Risk-Based Regulation: Choices, Practices and Lessons Being Learned, OECD Discussion Paper, Paris 2009, s. 8.

${ }^{5}$ Chodzi o wartości chronione środkami nadzoru administracyjnego. Wartości te powinny być określone ustawą, np. jako cele organu nadzoru.

6 J. Black, op. cit., s. 8.

${ }^{7}$ IOPS Toolkit, Module 1, Supervisory Management Issues, http://www.iopstoolkit.org/toolkitmodule1.html (dostęp: 2.03.2012). 
chronionym przez ten organ, a także ocenia, jakiej wielkości jest to zagrożenie, jakiego rodzaju czynniki ryzyka oddziaływania wchodzą w rachubę i jakie moga być konsekwencje zmaterializowania się ryzyka. Na podstawie tak przeprowadzonej analizy powstaje pewnego rodzaju „mapa” ryzyka obszaru nadzorowanego, która pozwala na sporządzenie wariantów nadzoru, ustalenie apetytu organu nadzoru na ryzyko oraz podjęcie decyzji co do działań nadzorczych mających mitygować ryzyko.

Powyższe działania organu nadzoru są konsekwencją tego, że zarządzanie ryzykiem organu nadzoru (czy też ściślej: ryzykiem celów organu nadzoru) będzie wpisywało się w ogólną koncepcję zarządzania ryzykiem i będzie polegało na przejściu organu administracji przez cztery etapy zarządzania ryzykiem:

1) identyfikację ryzyka,

2) pomiar i analizę ryzyka,

3) sterowanie ryzykiem ${ }^{8}$,

4) monitorowanie i kontrolę ryzyka ${ }^{9}$.

Jak wynika z powyższego, organ nadzoru, stosując NPR, w pierwszej kolejności rozpozna potencjalne czynniki ryzyka zagrażające celom organu w ramach nadzorowanego obszaru. Oczywiście przy założeniu, że wcześniej zostały zidentyfikowane cele organu nadzoru. Następnie wymierzy ryzyko w określonych jednostkach, tak aby można było je porównać i ocenić. Pomiaru ryzyka dokonuje się $\mathrm{w}$ kategoriach prawdopodobieństwa jego wystąpienia oraz następstw, gdyby wystapiło, a każda z tych kategorii może być mierzona w kilkustopniowej skali. Następnie organ nadzoru podejmuje decyzje o postapieniu ze stwierdzonymi ryzykami i zastosowaniu odpowiednich środków. Tutaj warto wskazać, że istnieją trzy możliwe metody postąpienia z ryzykiem:

1) transfer (przeniesienie) ryzyka (np. na ubezpieczyciela przez wykupienie ubezpieczenia),

2) redukowanie lub usunięcie ${ }^{10}$ ryzyka,

3) podjęcie ryzyka.

$\mathrm{Na}$ ostatnim etapie następuje sprawdzenie, jak działa proces zarządzania ryzykiem, jaka jest jego skuteczność, a w razie stwierdzenia takiej konieczności następuje dostosowanie zarządzania ryzykiem do aktualnego stanu rzeczy oraz potrzeb danego podmiotu.

W literaturze wskazuje się także na inne ujęcia zarządzania ryzykiem, które - trzymając się wskazanej wyżej osi konstrukcyjnej - wyróżniają także inne etapy tego procesu. Na przykład T. Kaczmarek wskazuje, że na zarządzanie ryzykiem składają się następujące etapy:

1) identyfikacja ryzyka - ustalenie czynników ryzyka, podmiotów dotkniętych ryzykiem oraz możliwych następstw materializacji ryzyka,

${ }^{8}$ Proponuję ten etap nazwać ,,postapienie z ryzykiem”.

${ }^{9}$ U. Malinowska, Charakterystyka kluczowych koncepcji zarzadzania ryzykiem w przedsiębiorstwie, w: S. Kasiewicz (red.), Zarzadzanie zintegrowanym ryzykiem przedsiębiorstwa w Polsce, Warszawa 2011, s. 64 .

${ }^{10} \mathrm{~W}$ kategoriach pojęć metod zarządzania ryzykiem nazywa się to mitygacją ryzyka. To pojęcie będzie wykorzystywane w dalszej części niniejszego opracowania. 
2) analiza ryzyka - ustalenie prawdopodobieństwa zaistnienia zdarzeń ryzyka oraz ich konsekwencji (jest to etap pogłębionej analizy ustaleń $\mathrm{z}$ etapu 1),

3) sformułowanie wariantów - ustalenie możliwości zarządzania ryzykiem oraz analiza nakładów i kosztów poszczególnych wariantów,

4) ocena apetytu na ryzyko - określenie gotowości do akceptacji ryzyka i określenie jego poziomu,

5) decyzje co do działań i ich wdrożenie w obszarze ryzyka - ustalenie sposobów mitygacji ryzyka i ich wdrożenie,

6) kontrola, monitoring i ocena podjętych działań ${ }^{11}$.

Trzymając się jednak najprostszej konstrukcji i przenosząc ją na grunt organów nadzoru administracyjnego, należy zwrócić uwagę przede wszystkim na etap postapienia $\mathrm{z}$ ryzykiem (sformułowanie wariantów, ocena apetytu na ryzyko oraz decyzji w ujęciu T. Kaczmarka). W tym wypadku bowiem zachodza istotne różnice w odniesieniu do organizacji innych niż administracja publiczna. Nie wchodzi tutaj na przykład w rachubę możliwość transferu całego ryzyka na ubezpieczyciela. Wprawdzie organ nadzoru może (w teorii lub w praktyce) wykupić określone ubezpieczenie, mimo to jednak nie może zwolnić się z wykonywania swoich kompetencji $\mathrm{w}$ najlepszy $\mathrm{z}$ możliwych sposobów i nie może zwolnić się ze społecznych konsekwencji swojego nieprawidłowego działania, np. upadłości instytucji finansowych. Inną kwestią wyróżniająca ten etap w działaniach organu nadzoru są środki mitygacji ryzyka organu administracji. $\mathrm{W}$ nadzorze administracyjnym bowiem mitygacja ryzyka polega na przeprowadzeniu oceny nadzorczej ryzyka danego podmiotu oraz oceny zastosowanych przez konkretny podmiot środków zarządzania ryzykiem, a następnie na zastosowaniu działań nadzorczych mających na celu mitygację ustalonego ryzyka na poziomie konkretnego podmiotu nadzorowanego ${ }^{12}$. I tutaj pojawia się kwestia sposobu, w jaki dokonuje się pomiaru ryzyka na poziomie makro. Podstawowym narzędziem jest ocena ryzyka na poziomie podmiotu podlegajacego nadzorowi, a więc na poziomie mikro-NPR. Zatem procedurę zarządzania ryzykiem przeprowadza się dla konkretnego podmiotu nadzorowanego, jednakże dokonuje się tego z perspektywy organu nadzoru.

Narzędzia nadzorcze mikro-NPR polegają na ocenie ryzyka podmiotu, przy uwzględnieniu metod zarządzania ryzykiem stosowanych $\mathrm{w}$ tym podmiocie. I w tym miejscu należy odwołać się do kategorii pojęciowych ryzyka rezydualnego oraz ryzyka inherentnego. W wypadku ryzyka rezydualnego chodzi o ocenę całości ryzyka, jakie generuje dany podmiot, a inherentnego - ocenę ryzyka, jakie generuje dany podmiot już po zastosowaniu narzędzi służących do mitygacji ryzyka rezydualnego. A oceniając ryzyko na poziomie danego podmiotu (mikro-NPR), organ nadzoru ocenia, jakie ryzyko inherentne generuje dany podmiot. Następnie organ dokonuje oceny takiego podmiotu oraz stosuje środki nadzorcze stosowne do poziomu ryzyka generowanego przez dany podmiot oraz stosowne do wpływu, jaki wywarłoby zmaterializowanie się

\footnotetext{
11 Opracowanie na postawie T. Kaczmarek, Ryzyko i zarzadzanie ryzykiem. Ujęcie interdyscyplinarne, Warszawa 2006, s. 98.

${ }^{12} \mathrm{~Np}$. poprzez zwiększenie wielkości wymaganego kapitału własnego danego podmiotu.
} 
ryzyka w danym podmiocie. W zależności od wyniku uzyskanego w toku procedury makro-NPR analiza konkretnego podmiotu może być szersza lub węższa, w zależności od ryzyka generowanego przez dany podmiot.

Zatem w tym ujęciu mitygacja ryzyka organu nadzoru (makro-NPR) staje się procesem zarządzania ryzykiem konkretnego, jednostkowego podmiotu nadzorowanego, a proces ten jest zarządzany przez organ nadzoru administracyjnego. Można zatem postawić tezę, że NPR w ujęciu mikro jest częścią NPR w ujęciu makro. Innymi słowy, makro-NPR to zagregowane mikro-NPR.

\section{Rysunek 1}

Mikro- i Makro-NPR

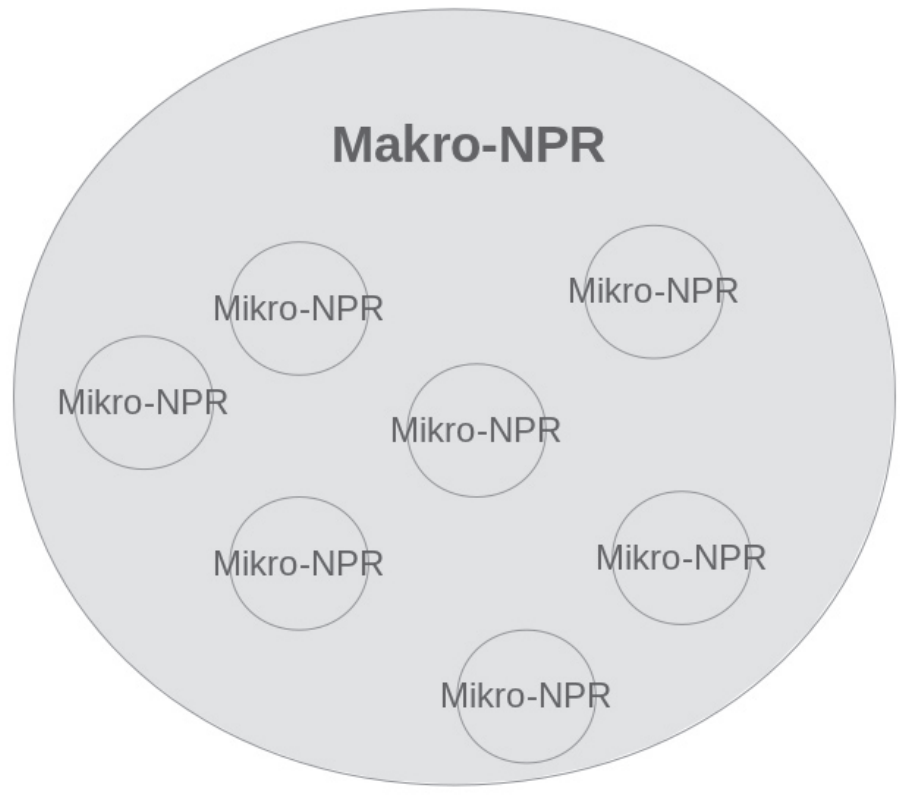

Na ujęciu mikro-NPR bazuje podejście NPR opracowane w Międzynarodowej Organizacji Nadzorów Funduszy Emerytalnych (International Organization of Pension Funds Supervisors - IOPS). W tym ujęciu NPR to metoda polegająca na identyfikacji potencjalnego ryzyka zagrażającego nadzorowanym podmiotom oraz ocenie nadzorczej finansowych i operacyjnych czynników zastosowanych w celu jego minimalizacji oraz mitygacji ${ }^{13}$ przez ten podmiot. Jednakże metodologia IOPS odwołuje się również do ujęcia makro i przywołanej wcześniej definicji J. Black ${ }^{14}$. Mikro-NPR jest również podstawą definicji NPR

\footnotetext{
${ }^{13}$ IOPS Toolkit, Module 2, Quantitative Risk Assessment Tools, http://www.iopstoolkit.org/ toolkit-module2.html (dostęp: 2.03.2012).

${ }^{14}$ IOPS Toolkit, Module 1, Supervisory Management Issues, http://www.iopstoolkit.org/toolkitmodule1.html (dostęp: 2.03.2012) i tam przywołana J. Black.
} 
przedstawionej przez Bank Światowy, ale także i tutaj zawarty jest element agregacji mikro-NPR $\mathrm{w}$ metodologię makro-NPR. Zgodnie $\mathrm{z}$ nią NPR to usystematyzowany proces mający na celu identyfikację ryzyka (na które narażony jest każdy podmiot), dokonywaną przez instytucję nadzorczą za pomocą oceny zarządzania ryzykiem oraz za pomocą oceny wrażliwości finansowej podmiotu na potencjalne niekorzystne zdarzenia (stress testy) ${ }^{15}$. Tutaj nowy element stanowią testy stresu, które są zagadnieniem wymagającym odrębnego opracowania.

Warto odnotować również, że na poziomie mikro przed ryzykiem chroni się podmioty. To podmioty nadzorowane pełnia istotne społecznie funkcje, co leży u podstaw objęcia ich nadzorem publicznym, i to nieprawidłowe funkcjonowanie tych podmiotów może spowodować zagrożenie ich istnienia, a w konsekwencji negatywne skutki społeczne. Jednakże na poziomie makro, jak się wydaje, przed ryzykiem chroni się już nie podmiot (organ administracji), ale cele, jakie ten organ administracji ma realizować. Ryzyko nie zagraża organowi, dlatego że jego byt konstytuowany jest ustawowo, a ponadto realizacja jego zadań nie przekłada się na jego trwanie. Zatem jest tu inaczej niż $\mathrm{w}$ sferze prawa prywatnego, w którym prawne i ekonomiczne istnienie podmiotu jest uzależnione od tego, jak skutecznie realizuje on ustanowione cele gospodarcze. Tymczasem organ administracji jest $\mathrm{w}$ tym sensie trwały, że jego istnienie nie jest uzależnione od stopnia realizacji celów. Ewentualne negatywne konsekwencje stwarzaja ryzyko dla piastuna organu, ale nie to jest przedmiotem niniejszej analizy. Zatem mogą się pojawić zagrożenia celów realizowanych przez organ administracji ( $R T O$ - risk to objectives).

\section{Definiowanie wartości chronionych NPR}

Zanim nastąpi zarządzanie ryzykiem w ramach zarysowanego wyżej modelu ogólnego, organ nadzoru powinien przede wszystkim określić, co chce (powinien) chronić przed ryzykiem. Tutaj praktyka najbardziej rozwiniętych nadzorów rynku finansowego pokazuje pewne zróżnicowanie. I tak brytyjski FSA chroni cele wyznaczone przez akt regulujący działanie tego organu, tj. Financial Services and Markets Act (2000), który wskazuje FSA następujące cele ${ }^{16}$ :

1) utrzymanie zaufania do systemu finansowego Wielkiej Brytanii,

2) promowanie szerokiego zrozumienia systemu finansowego,

3) zabezpieczenie i odpowiedni stopień ochrony konsumentów na rynku finansowym,

4) redukcja przestępczości finansowej.

Dla tak określonych ustawowo celów brytyjski FSA sporządził mapę ryzyka oraz określił metody dalszego postępowania w ramach NPR.

${ }^{15}$ Analitical Tools of the FSAP, dokument z lutego 2003 r., w: Wykorzystywanie testów stresu w procesie nadzoru nad zaktadami ubezpieczeń, Urząd Komisji Nadzoru Finansowego, Warszawa 2009, cyt. za: A. Nadolska, op. cit., s. 53.

${ }^{16}$ Na podstawie The FSA's Risk-Assessment Framework, the Financial Services Authority, Londyn, 2006 , s. 38 . 
Z kolei w wypadku Australian Prudential Regulation Authority (APRA) i zbudowanej przez ten organ metody PAIRS (Probability and Impact Rating System), a także nadzorcy holenderskiego De Nederlandsche Bank (DNB) i jego metody FIRM (Financial Institutions Risk Analysis Method), mamy już do czynienia nie z zespołem celów, jak w wypadku brytyjskim, ale z jednym celem $\mathrm{w}$ postaci zagwarantowania bezpieczeństwa finansowego podmiotów nadzorowanych ${ }^{17}$.

Zatem zanim organ nadzoru przejdzie do konstruowania własnej metody nadzoru w podejściu NPR, powinien zdefiniować to, co chce (powinien) ochraniać przed ryzykiem. Najbardziej ogólnym ujęciem tego, co jest chronione, sa, jak się wydaje, cele organu nadzoru. Wprawdzie można również mówić o wartościach chronionych przez ten organ, co również jest ujęciem ogólnym i mogącym pomieścić szerokie spektrum zjawisk, ale ochrona każdej wartości może być ujęta także jako cel organu nadzoru, co pozwala uznać, że cele organu nadzoru są pojęciem szerszym i lepiej służącym potrzebom określania ryzyka. Oczywiście określając cele organu nadzoru, należy zwrócić szczególną uwagę na cele tego organu wskazane w ustawach konstytuujących dany organ. Jednakże wyraźne wskazanie celów organu w ustawach ustrojowych nie zawsze ma miejsce. Jeśli cele są wskazane expressis verbis, sytuacja jest względnie prostanależy je wziąć pod uwagę. Nie wyklucza to jednak i nie powinno wykluczać możliwości zdefiniowania innych celów przez organ lub też sparafrazowania celów ustanowionych właśnie dla celów zarządzania ryzykiem. Ta uwaga odnosi się w szczególności do polskiej rzeczywistości normatywnej, w której wskazywanie celów organom administracji nie jest częstą praktyką. Jeśli ustawa ustrojowa nie wskazuje expressis verbis celów organowi, który ustanawia, to organ sam może te cele określić. W takim wypadku można je wywieść w drodze wnioskowania uogólniającego na podstawie szczegółowych kompetencji organu i wartości chronionych poszczególnymi przepisami publicznoprawnymi. Organ powinien wziąć pod uwagę wszelkie normy prawne, jakie regulują działalność tego organu, oraz ratio legis każdej z norm kompetencyjnych i na ich podstawie ustalić cele swojego istnienia i działania. Innymi słowy, cele organu można wywodzić z ogółu norm prawnych regulujących ingerencję organu administracyjnoprawnego $\mathrm{w}$ określony obszar życia społecznego. Wydaje się także, że ustawowo określone cele moga zostać przeformułowane w drodze wykładni tak, aby lepiej służyły zarządzaniu ryzykiem tych celów. Oczywiście zawsze z zachowaniem ich istoty.

\section{Identyfikacja ryzyka oraz ocena}

Dopiero po zidentyfikowaniu wartości, jakie maja podlegać ochronie przed ryzykiem, można rozpocząc stosowanie podejścia zarządzania ryzykiem według metod zasygnalizowanych powyżej.

Etap identyfikacji ryzyka polega na odnalezieniu takich zjawisk, które moga stworzyć ryzyko dla celów organu nadzoru czy też wartości chronionych przez

17 J. Black, op. cit., s. 12. 
ten organ. Ryzyko to można następnie zmierzyć i ująć je jako wynik współzależności dwóch czynników:

1) rozmiaru negatywnych konsekwencji (wpływu), jakie pojawią się, jeśli wystąpi określone wydarzenie (materializacja ryzyka),

2) prawdopodobieństwo wystapienia tego zdarzenia ${ }^{18}$.

Powyżej wskazana metoda polega na matematycznym określeniu obu wielkości: wpływu i prawdopodobieństwa, a następnie na matematycznym pomnożeniu obu liczb, w wyniku czego otrzymuje się określone wielkości dla poszczególnych ryzyk, które następnie mogą być sumowane. W wyniku tych działań można zakwalifikować dany podmiot do określonej grupy ryzyka dla osiagnnięcia celów (wartości) nadzoru, stosując np. macierze kwalifikacyjne. Oczywiście skale kwalifikacyjne moga być określane bardzo różnie, w zależności od czynników kształtujących obszar nadzorowany.

Tabela 1

Przykładowa tabela kwalifikacyjna

\begin{tabular}{|c|c|c|c|}
\hline wysokie ryzyko & & & \\
\hline średnie ryzyko & & & \\
\hline niskie ryzyko & & & \\
\hline RYZYKO/WPŁYW & niski wpływ & średni wpływ & wysoki wpływ \\
\hline
\end{tabular}

Taka kwalifikacja podmiotów pozwala na planowanie działań nadzorczych bazujących na generowanym ryzyku.

Warto $\mathrm{w}$ tym miejscu zaznaczyć, że wyniki oceny ryzyka na podstawie modeli matematycznych mogą być i w praktyce sa poddawane intuicyjnej, całościowej ocenie pracowników organu nadzoru, którzy na podstawie swojego doświadczenia oraz wiedzy o danym podmiocie nadzorowanym moga skorygować efekty takiej oceny. Wynika to z faktu, że w niektórych wypadkach modele matematyczne moga być zawodne i moga prowadzić do niewłaściwej oceny.

\section{KONSTRUOWANIE SYSTEMÓW NADZORU NA PODSTAWIE RYZYKA}

W opracowaniach przedmiotu wskazuje się, że organ nadzoru podczas konstruowania systemu NPR powinien podjąc trzy podstawowe kroki ${ }^{19}$. Po pierwsze - powinien określić poziom akceptowanego ryzyka (risk apetite), a więc określić, że w pewnych obszarach może dojść do materializacji ryzyka, wskutek czego wystapią negatywne konsekwencje, które organ akceptuje i podejmie on inne niż prewencyjne środki nadzorcze. Na przykład upadłość małego podmiotu

\footnotetext{
${ }^{18}$ Financial Services Authority, The FSA's Risk-Assessment Framework, sierpień 2006.

19 Opracowano na podstawie IOPS Toolkit, Module 1, Supervisory Management Issues, http://www. iopstoolkit.org/toolkit-module1.html (dostęp: 2.03.2012).
} 
działającego na rynku finansowym może zostać zdefiniowana przez organ nadzoru jako ryzyko, które moga ponieść zarówno jego akcjonariusze, jak $\mathrm{i}$ interesariusze, w szczególności klienci. Tego rodzaju decyzje są w praktyce konieczne, ponieważ realnie niemożliwe jest wyposażenie organów administracji w takie kompetencje i obciążenie podmiotów nadzorowanych takimi obowiązkami, żeby całkowicie wyeliminować wszelkie ryzyko. Zatem praktycznie pewne ryzyko, do pewnego poziomu, musi zostać zaakceptowane ${ }^{20}$. Ten poziom akceptowanego ryzyka będzie wynikiem szeregu czynników, jak np. obowiązków ustawowych czy też budżetu przeznaczonego dla danego organu.

Po drugie, organ nadzoru powinien także zidentyfikować ryzyko - instytucjonalne (dotyczące podmiotów) lub branżowe (przedmiotowe). Jeśli zatem celem nadzoru jest ochrona podmiotów przed upadłością (tak np. w nadzorze nad towarzystwami emerytalnymi), to organ nadzoru powinien zidentyfikować pełen zakres ryzyka, które może doprowadzić do upadłości tych podmiotów. W wypadku towarzystw emerytalnych może to być ryzyko rynkowe, kredytowe, operacyjne, compliance, zarządzania, przestępczości finansowej, outsourcingu itd.

Trzecią rzecza, którą powinien wykonać organ nadzoru jest mapowanie i ważenie ryzyka. W tej części organ nadzoru dokonuje oceny ryzyka systemowego, obciążającego branżę lub konkretny podmiot. Następnie ocenia środki, jakie znalazły zastosowanie w celu mitygacji tych rodzajów ryzyka, a potem ocenia potencjalny negatywny wpływ na cele organu nadzoru w sytuacji, gdyby zmaterializowało się ono mimo zastosowanych środków.

Zatem należy wskazać, że całościowa metodologia NPR (makro-NPR) wygląda następująco:

1) ocena całości obszaru nadzorowanego pod kątem występujących rodzajów ryzyka i ich wpływu na cele nadzorcze,

2) ustalenie podmiotów o największym potencjalnym negatywnym wpływie na cele nadzorcze

3) zhierarchizowanie tych podmiotów wg skali wpływu,

4) pogrupowanie podmiotów istotnych nadzorczo wg rozmiaru wpływu i ustalenie intensywności nadzoru nad tymi podmiotami,

5) opracowanie modeli nadzoru dla każdej z grup,

6) ocena ryzyk w podmiocie z grupy (mikro-NPR),

7) zastosowanie środków nadzorczych adekwatnych do ryzyka,

8) kontrola, ocena i ewentualna korekta podjętych działań ${ }^{21}$.

W tym momencie pojawia się kategoria cyku nadzorczego rozumianego jako powtarzanie oceny nadzorczej w pewnych, regularnych okresach. Mianowicie ocena ryzyka w podmiotach (mikro-NPR) powinna odbywać się w pewnych odstępach czasu, które zależą od ryzyka generowanego przez ten podmiot oraz od wpływu zmaterializowanego ryzyka tego podmiotu na sytuację w sektorze lub w szerszym obszarze życia społecznego.

${ }^{20}$ Zob. np. Financial Service Authority, Reasonable Expectations: Regulation in a Non Zero-Failure World, Londyn 2003, a także The APRA Supervision Blueprint, Sydney 2010, s. 8.

${ }^{21}$ Opracowano na podstawie The FSA's Risk-Assessment Framework, the Financial Services Authority, London 2006. 


\section{ZALETY I WADY NPR}

W literaturze zagranicznej podkreśla się zalety NPR, a liczne przykłady wdrożenia tej metody w praktyce administracji zdają się potwierdzać korzyści wynikające z jej zastosowania. Przede wszystkim wskazuje się, że NPR pozwala na optymalizację efektywności działań nadzorczych. Innymi słowy, NPR pozwala osiaggać dobrą, a być może najlepszą efektywność nadzorczą. Ta optymalizacja jest konsekwencja wielu cząstkowych czynników. NPR powoduje optymalizację alokacji ograniczonych zasobów organu nadzoru (chodzi o zasoby rzeczowe i osobowe) do zadań realizowanych przez nadzór. W ramach NPR bowiem największe zasoby sa kierowane tam, gdzie jest największe ryzyko, a więc tam, gdzie są one najbardziej potrzebne z punktu widzenia efektywnego nadzoru. To pozwala zmaksymalizować stopień realizacji celów nadzorczych przy określonym limicie środków przyznanych organowi nadzoru ${ }^{22}$. Ponadto wskazuje się, że NPR pozwala lepiej zaplanować i wykonywać działania nadzorcze będące odpowiedzią na określone zachowania podmiotów nadzorowanych ${ }^{23}$. Wynika to z faktu lepszego rozpoznania nadzorczego na etapie analizy ryzyka potencjalnych zdarzeń, które moga wymagać nadzorczej interwencji. Jeśli bowiem organ nadzoru uzna, że ryzykiem jest np. utrata płynności finansowej przez podmiot nadzorowany, to bezpośrednio po tym ustaleniu może, czysto teoretycznie, zaplanować możliwe ingerencje nadzorcze, np. konieczność skłonienia podmiotu nadzorowanego do podniesienia w określony sposób jego kapitału. W praktyce administracji zachodnich tego rodzaju plany odpowiedzi nadzorczej powstaja i są skutecznie stosowane. Tego rodzaju podejście w konsekwencji zwiększa przejrzystość działań administracji i stopień równości w traktowaniu podmiotów nadzorowanych. NPR jest ze swojej natury nadzorem przede wszystkim prewencyjnym. Analiza ryzyka i ocena podmiotów nadzorowanych pozwala wcześniej zasygnalizować nadzorowi, gdzie pojawiaja się sytuacje zagrażające bezpieczeństwu podmiotu nadzorowanego. To z kolei pozwala nadzorcy podjać odpowiednie działania jeszcze przed powstaniem problemu, którego konsekwencją byłaby upadłość podmiotu nadzorowanego. Zaletą NPR jest również to, że pozwala w miarę elastycznie modelować i określać relacje pomiędzy mitygacja ryzyka a poziomem swobody zachowań podmiotów nadzorowanych. Każdy bowiem rozwój wymaga pewnego zakresu swobody decydowania i możliwości podejmowania ryzyka. Całkowite wyeliminowanie ryzyka z działalności podmiotów spowodowałoby zamknięcie im drogi rozwoju. Tymczasem NPR nie eliminuje ryzyka, tylko umożliwia zarządzanie nim. Wszystkie powyższe elementy stanowią o skuteczności NPR i o coraz szerszym stosowaniu tej metody nadzoru w praktyce.

Rzadko wskazuje się jednak na wady NPR, a takie z całą pewnością istnieją. Pierwsza wada jest niejako drugim obliczem zalety. Otóż NPR, w wypadku założenia, że jego celem jest ochrona przed upadłością podmiotu nadzorowanego, wyłącza stosowanie mechanizmu rynkowego. Mechanizm rynkowy

${ }^{22}$ Zob. np. J. Black, op. cit., s. 7.

${ }^{23}$ Zob. np. ibidem. 
zakłada, że upadłość jest naturalną konsekwencją konkurencji, w wyniku której przedsiębiorcy lepiej zaspokajający potrzeby klientów uzyskuja przewagę i eliminują z rynku przedsiębiorców, którzy gorzej odpowiadaja na potrzeby klientów. Upadłość słabszych przedsiębiorców jest wpisana $\mathrm{w}$ istotę mechanizmu rynkowego. Tymczasem państwo, które za pomoca środków administracyjnych nie dopuszcza do upadłości gorszego przedsiębiorcy, stosuje środki o charakterze doradczym czy wręcz zarządzania (np. wydaje rekomendacje, zalecenia) albo o charakterze czysto ekonomicznym (np. dofinansowuje przedsiębiorcę), wyłącza stosowanie tego mechanizmu. Dalszym tego efektem jest tworzenie barier wejścia nowych przedsiębiorców na rynek. W wypadku bowiem upadłości jednego przedsiębiorcy zostaje po nim pewien udział w rynku, który moga zagospodarować nowo powstałe podmioty. Tymczasem odebranie klientów już obsługiwanym, lepiej lub gorzej, przez istniejące podmioty jest trudniejsze niż przejęcie klientów upadającego lub upadłego przedsiębiorcy. To powoduje ograniczenie efektywności mechanizmu rynkowego. Oczywiście jest też faktem, że gdy do upadłości przedsiębiorcy prowadzi mechanizm rynkowy (a nie np. katastrofa naturalna), ta upadłość wynika z zachowania konkretnych osób zarządzających tym podmiotem. Te zachowania mogą polegać na celowych działaniach lub też na błędach, głównie w prowadzeniu spraw gospodarczych przedsiębiorcy. NPR uwzględnia tę kwestię i zwraca uwagę na ryzyko ludzkie, w tym na ryzyko oszustw oraz ryzyko zarządzania. Ale w ten sposób, zwłaszcza w wypadku zarządzania, nadzór publiczny wkracza już w kompetencje właściciela, a więc w mechanizm rynkowy. Zatem i tak należy stwierdzić, że w ramach tej metody następuje daleko idąca ingerencja władz publicznych w mechanizm rynkowy.

Można również postawić tezę, że zaawansowany NPR jest nadzorem stosunkowo drogim. Koszty związane z zastosowaniem zaawansowanych rozwiązań NPR moga wyrażać się w dużych kwotach zarówno po stronie organu nadzoru, jak i po stronie podmiotów nadzorowanych, które sa zobligowane do wypełniania szeregu obowiązków informacyjnych. Rozwinięte metody NPR są też stosunkowo inwazyjne w tym sensie, że organ nadzoru wchodzi w posiadanie wielu istotnych informacji o podmiocie nadzorowanym. W wyniku zastosowania nowoczesnego NPR organ nadzoru może mieć np. codzienny wgląd w każdy obszar funkcjonowania podmiotu nadzorowanego. Bezpieczeństwo podmiotu wymaga bowiem całościowej oceny ryzyka tego podmiotu, a to wiąże się z pozyskiwaniem szerokiego zakresu informacji i z całościową oceną nadzorowanego podmiotu.

Kolejną wadą NPR, która może się ujawnić w warunkach niektórych kultur biznesowych i prawnych, jest wykorzystywanie zmniejszonej uwagi nadzorczej jako okazji czy wręcz zachęty do łamania prawa. Jest bowiem faktem, że NPR powstał i dynamicznie rozwija się w krajach anglosaskich, w których istotnym elementem kultury gospodarczej jest kategoria uczciwych zachowań (fair). Tymczasem $\mathrm{w}$ innych warunkach kulturowych jakaś część przedsiębiorców może wykorzystać fakt zaufania publicznego do danego sektora gospodarki, wynikający z podlegania nadzorowi publicznemu, do celowego oszukiwania klientów. Można sobie wyobrazić, że grupa osób utworzy instytucję finansowa wyłącznie w tym celu, aby zebrać pieniądze od klientów i wytransferować je 
w określony sposób na prywatne konta członków zarządu czy też wspólników. Jeśli sektor ma ogólny wizerunek budzącego zaufanie, a do tego podlega nadzorowi publicznemu, to potencjalni klienci moga zastosować zmniejszony stopień ostrożności wobec takich podmiotów. W sytuacjach tych NPR może ułatwiać nieuczciwym przedsiębiorcom działanie niezgodne z prawem przez to, że umożliwi takim podmiotom celowe ulokowanie się w takiej części mapy ryzyka nadzorcy, że jego uwaga poświęcona tym podmiotom będzie nieznaczna lub żadna. Nie wyklucza to jednak zastosowania NPR przez organy administracji sprawujące nadzór nad obszarami o takiej kulturze gospodarczej. W takich wypadkach można, jak się wydaje, przyjąć istotę NPR, należy jednak zastosować pewne korekty w poszczególnych elementach architektury systemu nadzoru NPR.

Powyższe wyliczenie wad nie zmienia jednak faktu, że korzyści wynikające z zastosowania NPR są bardzo duże. I te korzyści zachęcają zarówno ośrodki tworzace prawo do nakładania na administrację obowiązku stosowania tej metody, jak i same organy do jej wdrażania, niezależnie od tego, czy prawo nakłada na nie taki obowiązek.

\section{OBSZARY MOŻLIWEGO ZASTOSOWANIA}

Przede wszystkim należy wskazać, że NPR może być stosowany tam, gdzie celem organu nadzoru jest zapewnienie bezpieczeństwa jakiemuś podmiotowi (podmiotowi nadzorowanemu lub klientom tego podmiotu, jego pracownikom itd.) i gdzie istotną rolę odgrywa nadzór prewencyjny. NPR bowiem zwiększa prawdopodobieństwo wykrycia pojawiających się problemów podmiotu nadzorowanego na wczesnym etapie, umożliwiając tym samym nadzorczą reakcję i usunięcie zagrożeń. Metoda ta może być z powodzeniem stosowana również w sytuacjach, gdy obszary nadzorowane administracyjnie są rozległe podmiotowo i przedmiotowo, a w konsekwencji zasoby organu nadzoru nie pozwalaja na całościowy (podmiotowo lub przedmiotowo) nadzór nad obszarem powierzonym nadzorowi administracyjnemu. Metoda ta dobrze sprawdzi się, gdy w obrębie nadzorowanego obszaru funkcjonują podmioty o zróżnicowanej wielkości, ponieważ pozwala dopasować metody nadzoru adekwatnie do wpływu tych podmiotów na cele nadzorcze. W ramach NPR bowiem w stosunku do dużych podmiotów stosuje się bardziej szczegółowe środki nadzoru, a w stosunku do małych podmiotów - środki mniej absorbujące zasoby nadzorcze. NPR jest też stosowany w tych obszarach życia społecznego, w których podstawowa działalność nie powinna być bardzo ściśle reglamentowana, a więc tam, gdzie za wartość uznaje się określoną swobodę zachowań podmiotów nadzorowanych i innowacyjność ich działań, jednakże ze względu na doniosłość społeczną danego obszaru państwo ustanawia nad nim nadzór administracyjny. NPR bowiem jest metodą dopuszczająca szerokie spektrum zachowań podmiotów nadzorowanych oraz ich kreatywność w grze rynkowej i związane z tym ryzyko, a jednocześnie zapewnia ustalony poziom bezpieczeństwa tych podmiotów. Jak więc wynika $\mathrm{z}$ powyższego wyliczenia, zakres możliwych zastosowań NPR jest dość szeroki. W tym miejscu warto też zaznaczyć, że 
nominalnie NPR dotyczy tylko nadzoru, jednakże w części oceny ryzyka i podejmowania działań na tej podstawie równie dobrze nadaje się do stosowania w obszarach podlegających kontroli (a nie nadzorowi) administracyjnej.

Jako przykłady zastosowania w polskiej administracji metody NPR można wskazać obszar bezpieczeństwa żywności, gdzie regulacje europejskie wprowadzają w niektórych wypadkach wymogi administrowania na podstawie ryzyka (zob. regulacje rozporządzenia [WE] nr 882/2004 Parlamentu Europejskiego i Rady z 29 kwietnia 2004 r.). Innym przykładem może być administracja skarbowa, która w obszarze kontroli skarbowej wprowadziła system NPR ${ }^{24}$.

Wydaje się również, że na gruncie polskiej administracji NPR może być stosowany z powodzeniem w takich obszarach, jak ochrona środowiska, nadzór nad przestrzeganiem prawa pracy, nadzór budowlany, nadzór sanitarny, nadzór handlowy czy też nadzór nad ochroną danych osobowych. Powyższe wyliczenie bynajmniej nie pretenduje do zupełności.

NPR posiada liczne zalety, które wskazano w niniejszym tekście i które przesądzają o jego atrakcyjności dla administracji publicznej. W Polsce, jak się wydaje, nie jest to jeszcze popularna metoda administrowania, można mieć jednak nadzieję, że będzie się upowszechniać.

dr Mariusz Maciejewski

Instytut Nauk Prawnych Polskiej Akademii Nauk w Warszawie

mariusz.maciejewski@inp.pan.pl

\section{RISK-BASED SUPERVISION AS AN ADMINISTRATIVE SUPERVISION METHOD}

\section{Summary}

One of the significant functions performed by public administration is public supervision over a specified area of social life. Administrative supervisory authorities are given a range of competences for supervision purposes and subsequently decide how to perform them. Supervisory organs create methodologies of exercising their powers and seek optimal methods that will allow them to achieve objectives. Supervisors are often confronted with situations where areas under their supervision are very broad while the resources, especially human resources, that are available to them are insufficient to adequately and effectively cover all the supervised subjects. In such a situation the authority may exercise its powers only selectively and the method of execution of competences becomes a key issue. This paper presents one of such methods developed in practice and used in administrative supervision. It is a risk-based supervision (RBS) method and its genesis, context and nature as well as practical applications - current and potential are presented.

${ }^{24}$ Ścigamy coraz skuteczniej, wywiad z A. Parafianowiczem - Generalnym Inspektorem Kontroli Skarbowej, ,Rzeczpospolita” z 11 czerwca 2012 r. 
Copyright of Journal of Law, Economics and Sociology is the property of Faculty of Law and Administration of Adam Mickiewicz University in Poznan and its content may not be copied or emailed to multiple sites or posted to a listserv without the copyright holder's express written permission. However, users may print, download, or email articles for individual use.

Właścicielem praw autorskich do „Ruchu Prawniczego, Ekonomicznego i Socjologicznego” jest Wydział Prawa i Administracji Uniwersytetu im. Adama Mickiewicza w Poznaniu. Zawartość czasopisma nie może być kopiowana, przesyłana do innych stron internetowych bądź zamieszczana na blogach bez pisemnej zgody wydawcy. Niemniej artykuły można drukować, kopiować lub przesyłać w formie elektronicznej na własny użytek. 